\title{
Early results of excision of 220 cases of primary chest wall tumors in 12 year period
}

\author{
Amer Bilal \\ From World Society of Cardiothoracic Surgeons 25th Anniversary Congress, Edinburgh \\ Edinburgh, UK. 19-22 September 2015
}

\section{Background/Introduction}

Primary chest wall tumors originate from different constructions of thoracic wall. Resectable tumors are excised with primary closure or chest wall reconstruction with better outcome.

\section{Aims/Objectives}

To assess the surgical outcomes in primary chest wall tumor.

\section{Method}

220 patients from June 2002 to Dec 2014 were retrospectively analyzed. Patients of all ages, both sexes and operable primary chest wall tumor were included. Clinical evaluation, routine investigations, chest radiographs, computed tomography and biopsy were done. Incisional biopsy was done for $>5 \mathrm{~cm}$ mass while excisional biopsy was done in smaller tumors. Complete excision of the chest wall tumor with $5 \mathrm{~cm}$ free margin and one normal rib above and one normal rib below was done. Specimen was sent for histopathology. In skeletal reconstruction plastic surgeon was involved. Patients sent to oncologist for adjuvant therapy accordingly. One year follow-up were done.

\section{Results}

Out of 220 patients, 143 were male and 77 were female, age ranges from 9-80 years with a median of 27.8 years. 151 patients experienced painless mass and 69 patients painful mass.113 chest wall masses presented on right side, 70 left sided and 37 on sternum. Sizes were $<3 \mathrm{~cm}$ $78,3-5 \mathrm{~cm} \mathrm{92,5-10} \mathrm{cm} 42$ and $>10 \mathrm{~cm} \mathrm{08}$. Chest wall resection and primary closure was done in 107 cases while in 113 cases resection and reconstruction done using marlex mesh alone in 98 cases and reinforced

Dept of Cardiothoracic Surgery, Lady Reading Hospital, Peshawar, Pakistan with methyl methacrylate in 15 cases. Histologically Chondrosarcoma was reported in 61.5\%, Fibrosarcoma in $25 \%$, Ewing sarcoma in $11.5 \%$ while $2 \%$ specimens were reported as chondroma. Postoperative flail observed in 8cases, 5 patients died despite prolonged ventilation. All patients referred to oncologist post operatively. One year follow up of all 215 alive patients were tumor free.

\section{Discussion/Conclusion}

Primary chest wall tumor can be safely managed by resection and primary closure or chest wall reconstruction and are associated with long term survival.

Published: 16 December 2015

doi:10.1186/1749-8090-10-S1-A16

Cite this article as: Bilal: Early results of excision of 220 cases of primary chest wall tumors in 12 year period. Journal of Cardiothoracic Surgery 2015 10(Suppl 1):A16.
Submit your next manuscript to BioMed Central and take full advantage of:

- Convenient online submission

- Thorough peer review

- No space constraints or color figure charges

- Immediate publication on acceptance

- Inclusion in PubMed, CAS, Scopus and Google Scholar

- Research which is freely available for redistribution
() Biomed Central 